\title{
Quantitative Prediction of Magnesium Absorption in Dairy Cows
}

\author{
J. T. Schonewille, ${ }^{\star 1}$ H. Everts, ${ }^{\star}$ S. Jittakhot, $\dagger$ and A. C. Beynen* \\ *Department of Nutrition, Faculty of Veterinary Medicine, Utrecht University, PO Box 80152, 3508 TD Utrecht, the Netherlands \\ †Faculty of Veterinary Medicine, Mahidol University, Salaya Campus, Nakhon Pathom, Thailand
}

\begin{abstract}
The objective of the current study was to predict magnesium $(\mathrm{Mg})$ absorption in dairy cows based on data from our own studies and those of other investigators. Balance data from 15 independent studies with 68 different rations and 323 dairy cows or cow-periods were used. In 12 studies, grass feeds were the main source of roughage and in about one-half of the studies, $\mathrm{MgO}$ supplemented rations were used. Out of the 68 rations, 14 rations contained supplemental $\mathrm{K}$ in the form of bicarbonate, and in 2 rations additional $\mathrm{K}$ was incorporated mainly in form of $\mathrm{KCl}$. The $\mathrm{K}$ content of the rations ranged from 6.9 to $75.6 \mathrm{~g} / \mathrm{kg}$ of dry matter (DM; mean $29.4 \mathrm{~g} / \mathrm{kg}$ of DM). In most studies (10/15), dry, nonpregnant cows were used. For lactating animals, milk yield ranged from 4 to $22 \mathrm{~kg} / \mathrm{d}$ (mean yield, $15 \mathrm{~kg} / \mathrm{d}$ ). All studies provided quantitative information with respect to feed intake (DM intake, $\mathrm{Mg}$, and $\mathrm{K}$ ) and total $\mathrm{Mg}$ excretion in feces. The mean dietary $\mathrm{Mg}$ content was $4.5 \mathrm{~g} / \mathrm{kg}$ of DM and ranged from 0.45 to $17.3 \mathrm{~g} / \mathrm{kg}$ of DM. On average, $\mathrm{Mg}$ absorption (\% of intake) was $26.2 \%$ and ranged from 9.9 to $73.7 \%$. The variation in $\mathrm{Mg}$ absorption was at least partly explained by the variation in dietary $\mathrm{K}$ concentrations. Magnesium absorption (\% of intake) was significantly decreased by 0.31 percentage units/g of $\mathrm{K}$ in the DM. To counteract the depressant effect of dietary $\mathrm{K}$ on $\mathrm{Mg}$ absorption, $\mathrm{Mg}$ intake must be increased by $4 \mathrm{~g} / \mathrm{d}$ when the dietary $\mathrm{K}$ concentration increases by $10 \mathrm{~g} / \mathrm{kg}$ of $\mathrm{DM}$ so that the amount of absorbed $\mathrm{Mg}$ is maintained.
\end{abstract}

Key words: magnesium, absorption, potassium, model

\section{INTRODUCTION}

Magnesium plays an essential role in metabolism because it influences the activity of more than 300 cellular enzymes that are involved in energy metabolism and protein synthesis (Aikawa, 1981; Ryan, 1991). In cows, clinical hypomagnesemia (plasma $\mathrm{Mg}<0.4 \mathrm{mmol} /$

Received April 23, 2007.

Accepted September 11, 2007.

${ }^{1}$ Corresponding author: j.t.schonewille@vet.uu.nl
L) causes grass tetany (Sjollema, 1930), and subclinical hypomagnesemia (plasma $\mathrm{Mg}$ values ranging from 0.4 to $0.8 \mathrm{mmol} / \mathrm{L}$ ) seems to be associated with an increased incidence of milk fever (hypocalcemic paresis puerperalis; Van Leengoed, 1979; Barber et al., 1983). Thus, an adequate dietary supply of $\mathrm{Mg}$ is important.

The Dutch recommendation (CVB, 1996) for the requirement of $\mathrm{Mg}$ for dairy cows was calculated as: (2.5 $+0.12 \times \mathrm{M}) \times 100 / \mathrm{A}(\mathrm{g} / \mathrm{d})$. In this formula, the constant of 2.5 represents an estimation of the endogenous losses on the basis of balance trials with cows (Kemp et al., 1961), $\mathrm{M}=$ milk production in $\mathrm{kg} / \mathrm{d}, 0.12=\mathrm{Mg}$ content of milk, expressed in $\mathrm{g} / \mathrm{kg}$, and A represents the percentage of true $\mathrm{Mg}$ absorption. With respect to the percentage of $\mathrm{Mg}$ absorption, a value of $10 \%$ (\% of $\mathrm{Mg}$ intake) is recommended when rations are based on grass products, whereas values of 15 to $18 \%$ are recommended when the ration contains a significant amount of corn silage (CVB, 2005a). The difference in recommended values is related to the fact that the incorporation of a significant amount of corn silage lowers the potassium concentration of the ration because corn silage is much lower in $\mathrm{K}$ than grass feeds such as hay, silage, and fresh grass (i.e., 12.0 vs. $24.1,34.1$, and 36.6 $\mathrm{g} / \mathrm{kg}$ of DM respectively; CVB, 2005b). Indeed, it is well known that dietary $\mathrm{K}$ has a depressant effect on $\mathrm{Mg}$ absorption in ruminants (Schonewille, 1999).

For dairy cows fed corn silage-based rations, with a mean dietary $\mathrm{K}$ content of $16 \mathrm{~g} / \mathrm{kg}$ of DM (ranging from 10.7 to $26.5 \mathrm{~g}$ of $\mathrm{K} / \mathrm{kg}$ of DM), a quantitative relationship between the dietary $\mathrm{K}$ content and apparent $\mathrm{Mg}$ absorption was reported by Weiss (2004). However, dairy rations based on grass feeds usually contain much more $\mathrm{K}$ and it is not clear whether the reported quantitative relationship between dietary $\mathrm{K}$ and $\mathrm{Mg}$ absorption (Weiss, 2004) can be extrapolated to rations with greater dietary K concentrations. Therefore, an attempt was made to quantify the relationship between dietary $\mathrm{K}$ and $\mathrm{Mg}$ absorption in rations containing $\mathrm{K}$ in the range from 6.9 to $75.6 \mathrm{~g} / \mathrm{kg}$ of DM with a mean dietary content of $29.4 \mathrm{~g} / \mathrm{kg}$ of DM (SD \pm 12.8 ). The range in dietary $\mathrm{K}$ concentrations in the data set used is beyond the practical range (Schonewille et al., 1997), but we anticipated that this would enhance the proper predic- 
tion of the inhibitory effect of $\mathrm{K}$ on $\mathrm{Mg}$ absorption. Because data from $\mathrm{Mg}$ balances obtained from sheep cannot be extrapolated quantitatively to cows (Adediji and Suttle, 1999; Schonewille, 1999), only reported data from studies with cows are used.

\section{MATERIALS AND METHODS}

\section{Data Set}

Balance data from 15 independent studies with 68 different rations and 323 dairy cows or cow-periods (when experiment was designed as a Latin square) were used (Table 1). A general description with respect to the rations and animals used is provided in Table 2. Briefly, in 12 studies, grass feeds were the main source of roughage; and in about half of the studies, $\mathrm{MgO}$ supplemented rations were used (Table 2). Out of the 68 rations, 14 rations contained supplemental $\mathrm{K}$ in the form of bicarbonate, and in 2 rations additional $\mathrm{K}$ was incorporated mainly in form of $\mathrm{KCl}$ (Table 2). In most studies (10 of 15), dry, nonpregnant cows were used. For lactating animals, milk yield ranged from 4 to 22 $\mathrm{kg} / \mathrm{d}$ and mean milk yield was about $15 \mathrm{~kg} / \mathrm{d}$. All studies provided quantitative information with respect to feed intake (DMI, $\mathrm{Mg}$, and $\mathrm{K}$ ) and total $\mathrm{Mg}$ excretion in feces. Magnesium absorption was a main objective in each study.

Clearly, absorption data obtained from balance trials only provide information on apparent $\mathrm{Mg}$ absorption; that is, $\mathrm{Mg}$ intake (g/d) - fecal Mg excretion (g/d). Because it is preferred to derive $\mathrm{Mg}$ allowances based on a factorial approach (CVB, 2005b) including the net maintenance requirement of $\mathrm{Mg}$, apparent $\mathrm{Mg}$ absorption has to be converted into true $\mathrm{Mg}$ absorption. The endogenous fecal $\mathrm{Mg}$ losses in cattle are estimated to be $4 \mathrm{mg} / \mathrm{kg}$ of BW (Schonewille and Beynen, 2005) and are assumed to be inevitable and constant; that is, independent of $\mathrm{Mg}$ intake. Thus, absolute true $\mathrm{Mg}$ absorption $(\mathrm{g} / \mathrm{d})$ was estimated by using the calculated endogenous fecal $\mathrm{Mg}$ losses and the observed apparent $\mathrm{Mg}$ absorption $(\mathrm{g} / \mathrm{d})$ : true $\mathrm{Mg}$ absorption $=\mathrm{Mg}$ intake - fecal $\mathrm{Mg}+$ endogenous fecal $\mathrm{Mg}$, where endogenous fecal $\mathrm{Mg}=4 \mathrm{mg} / \mathrm{kg}$ of BW. The values for true $\mathrm{Mg}$ absorption are given in Table 1 .

\section{Statistical Analyses}

Data were analyzed with the SAS statistical package (SAS Institute, 2003). The MIXED procedure was used to evaluate the relationships between true $\mathrm{Mg}$ absorption, expressed either in absolute terms $(\mathrm{g} / \mathrm{d})$ or relative to $\mathrm{Mg}$ intake (\% of intake) and the dependent variables $\mathrm{K}$ intake (g/d), Mg intake (g/d), DMI (kg/d), the K content of the ration $(\mathrm{g} / \mathrm{kg}$ of $\mathrm{DM})$, and the $\mathrm{Mg}$ content of the ration $(\mathrm{g} / \mathrm{kg}$ of $\mathrm{DM})$. It turned out that $\mathrm{DMI}$ and both $\mathrm{Mg}$ intake and $\mathrm{K}$ intake were significantly $(P<$ 0.016 ) correlated. Thus, DMI was not used as a dependent variable when either $\mathrm{Mg}$ or $\mathrm{K}$ intake was incorporated into the model. Trial was included as a random class variable (St-Pierre, 2001) and the dependent variables were included as continuous variables.

\section{RESULTS AND DISCUSSION}

It is well known that both dietary $\mathrm{Mg}$ and $\mathrm{K}$ are important determinants of $\mathrm{Mg}$ absorption in ruminants (Brown et al., 1978; Martens, 1979; Care et al., 1984; Martens et al., 1987; Leonhard et al., 1989; LeonhardMarek and Martens, 1996). However, Kemp (1960) suggested that dietary CP might interfere with Mg absorption because signs of tetany were observed when cows were fed herbage heavily fertilized with N. However, under controlled feeding conditions, dietary CP did not affect $\mathrm{Mg}$ absorption (Grace and MacRae, 1972; Moore et al., 1972; Fontenot et al., 1973; Gäbel and Martens, 1986). Furthermore, a wide array of dietary compounds in relation to $\mathrm{Mg}$ absorption, including $\mathrm{CP}$, was recently evaluated by Weiss (2004) and it was found that only $\mathrm{Mg}$ intake and dietary $\mathrm{K}$ concentration were significantly related to $\mathrm{Mg}$ absorption. Furthermore, in all studies mentioned in Table 1, dietary CP was not variable at constant $\mathrm{K}$ intakes, which makes it difficult to demonstrate a specific effect, if any, of $\mathrm{CP}$ on $\mathrm{Mg}$ absorption. Therefore, the data set used in the current study only contains variables related to $\mathrm{Mg}$ and $\mathrm{K}$ intake.

When true $\mathrm{Mg}$ absorption is regressed on $\mathrm{Mg}$ intake (adjusted for trial effects) the following equation was estimated:

$$
\begin{gathered}
\text { True } \mathrm{Mg} \text { absorption }(\mathrm{g} / \mathrm{d})= \\
1.3( \pm 0.67)+0.20( \pm 0.01) \times \mathrm{Mg} \text { intake }(\mathrm{g} / \mathrm{d}) .
\end{gathered}
$$

The values in parentheses represent the standard errors of the coefficients. The residual standard error (SE $\mathbf{S E S}_{\mathbf{R E S}}$ ) was found to be 0.38 and the standard error associated with trial ( $\mathbf{S E}_{\text {TRIAL }}$ ) was 1.48. The slope of equation [1] was significantly different from zero $(P<$ 0.001 ) whereas the intercept tended to be significantly different from zero $(P=0.065)$, which is unwanted because an estimate of absolute true $\mathrm{Mg}$ absorption $(\mathrm{g} / \mathrm{d})$ was used as an independent variable. Our estimation of the endogenous fecal $\mathrm{Mg}$ losses may be overestimated. Indeed, on the basis of an isotope dilution method, Simesen et al. (1962) reported a value of $1.5 \mathrm{mg} / \mathrm{kg}$ of $\mathrm{BW}$. On the other hand, on the basis of feeding artificial rations low in $\mathrm{Mg}$, Rook et al. (1964) estimated an endogenous fecal $\mathrm{Mg}$ loss of $6 \mathrm{mg} / \mathrm{kg}$ of BW. It can be 
Table 1. Data used for regression analysis

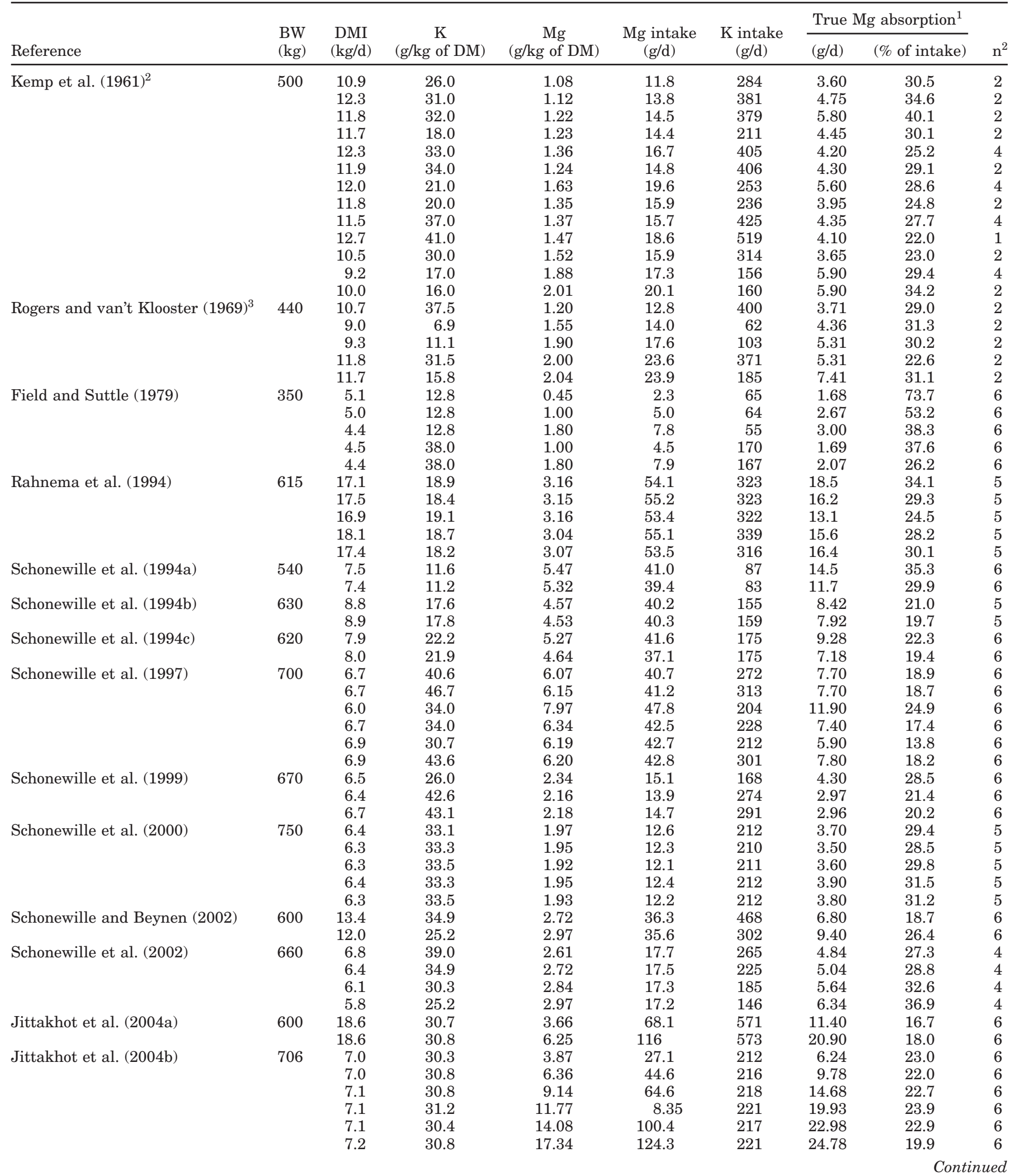


Table 1 (Continued). Data used for regression analysis

\begin{tabular}{|c|c|c|c|c|c|c|c|c|c|}
\hline \multirow[b]{2}{*}{ Reference } & \multirow{2}{*}{$\begin{array}{l}\text { BW } \\
(\mathrm{kg})\end{array}$} & \multirow{2}{*}{$\begin{array}{c}\mathrm{DMI} \\
(\mathrm{kg} / \mathrm{d})\end{array}$} & \multirow{2}{*}{$\begin{array}{c}\mathrm{K} \\
(\mathrm{g} / \mathrm{kg} \text { of } \mathrm{DM})\end{array}$} & \multirow{2}{*}{$\begin{array}{c}\mathrm{Mg} \\
(\mathrm{g} / \mathrm{kg} \text { of } \mathrm{DM})\end{array}$} & \multirow{2}{*}{$\underset{(\mathrm{g} / \mathrm{d})}{\mathrm{Mg} \text { intake }}$} & \multirow{2}{*}{$\underset{(\mathrm{g} / \mathrm{d})}{\mathrm{K} \text { intake }}$} & \multicolumn{2}{|c|}{ 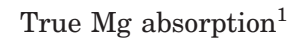 } & \multirow[b]{2}{*}{$\mathrm{n}^{2}$} \\
\hline & & & & & & & $(\mathrm{g} / \mathrm{d})$ & (\% of intake) & \\
\hline \multirow[t]{5}{*}{ Jittakhot et al. (2004c) } & 790 & 7.1 & 20.5 & 5.80 & 41.1 & 145 & 8.36 & 20.3 & 6 \\
\hline & & 8.0 & 75.6 & 5.02 & 40.0 & 602 & 3.96 & 9.9 & 6 \\
\hline & & 7.1 & 20.9 & 9.69 & 68.9 & 149 & 15.96 & 23.2 & 6 \\
\hline & & 7.5 & 47.8 & 9.25 & 69.6 & 360 & 12.06 & 17.3 & 6 \\
\hline & & 8.0 & 75.5 & 8.55 & 68.7 & 607 & 7.96 & 11.6 & 6 \\
\hline
\end{tabular}

${ }^{1}$ True $\mathrm{Mg}$ absorption (g/d) was calculated as Mg intake (g/d) - fecal Mg excretion (g/d) $+0.004 \times \mathrm{BW}$.

${ }^{2}$ Number of cows on each ration.

${ }^{3}$ Data from individual cows fed similar diets were pooled.

suggested that BW is not the sole determinant of endogenous fecal Mg loss, but that DMI might also be important. However, as far as we know, there are insufficient data to quantify a reliable relationship between endogenous fecal Mg losses and DMI. Clearly, this issue is not yet settled.

In our data set, mean $\mathrm{Mg}$ intake (37.7 g/d, Table 3) was associated with a mean estimated $\mathrm{Mg}$ absorption of $23.0 \%$ of $\mathrm{Mg}$ intake (equation [1]); a value resembling the number reported by Weiss $(2004 ; 18.5 \%$ of $\mathrm{Mg}$ intake). The discrepancy between our estimate of efficiency of $\mathrm{Mg}$ absorption and the value reported by Weiss (2004) may be explained by the fact that an estimate of true $\mathrm{Mg}$ absorption is used in the current study, whereas Weiss (2004) used apparent Mg absorption. Furthermore, compared with the current data set (Table 1 ), the mean dietary $\mathrm{K}$ content in the data set used by Weiss (2004) was considerably lower (30.3 vs. 16.0 $\mathrm{g} / \mathrm{kg}$ of DM, respectively). Alternatively, we cannot exclude the possibility that the difference in $\mathrm{Mg}$ absorption (\% of intake) calculated from equation [1] and the value reported by Weiss (2004) is related to a difference in DMI. Indeed, the equation provided by Weiss (2004) is based on studies with lactating cows, whereas equation [1] was primarily based on studies with dry, nonpregnant cows with corresponding lower DMI (Table 2 ). However, there is evidence that $\mathrm{Mg}$ absorption might not be sensitive to DMI. It has been shown that dry and lactating cows are equally efficient in $\mathrm{Mg}$ absorption (\% of intake) when DMI (Mg content of the ration was either 3.8 or $6.4 \mathrm{~g} / \mathrm{kg}$ of $\mathrm{DM}$ ) increased from 7 to 18.6 $\mathrm{kg} / \mathrm{d}$ (Jittakhot et al., 2004a).

The observed reduction in $\mathrm{Mg}$ absorption in ruminants at high K intakes (Ram et al., 1998; Schonewille et al., 1999; Jittakhot et al., 2004c) can be explained by the depolarizing action of high luminal $\mathrm{K}$ concentrations on the apical membrane potential of rumen epithelium cells, which reduces the driving force for $\mathrm{Mg}$ uptake by these cells (Martens et al., 1987; LeonhardMarek and Martens, 1996). Consequently, the negative effect of $\mathrm{K}$ intake on $\mathrm{Mg}$ absorption should be taken into account when predicting $\mathrm{Mg}$ absorption. In the practice of feed formulation it is preferred to calculate the required amount of dietary $\mathrm{Mg}$ on the basis of net $\mathrm{Mg}$ requirement and the efficiency of true $\mathrm{Mg}$ absorption. Thus, prediction of $\mathrm{Mg}$ absorption expressed as a percentage of $\mathrm{Mg}$ intake, would be of practical relevance. Various regression models were evaluated (Table 4) to assess true $\mathrm{Mg}$ absorption (\% of intake); the model (adjusted for trial effects) showing the lowest residual standard error (5.99) appeared to be (SE $\mathrm{SERIAL}_{\mathrm{T}}$ 17.8; $P$ INTERCEPT, SLOPE $<0.001)$ :

$$
\begin{gathered}
\mathrm{Mg} \text { absorption }(\% \text { of intake })=34.9( \pm 2.62) \\
-0.31( \pm 0.068) \times \text { dietary } \mathrm{K}(\mathrm{g} / \mathrm{kg} \text { of } \mathrm{DM})
\end{gathered}
$$

A similar equation was reported by Weiss (2004): $\mathrm{Mg}$ digestibility $=31.6( \pm 6.3)-0.75( \pm 0.35) \times$ dietary $\mathrm{K}(\mathrm{g} /$ $\mathrm{kg}$ of $\mathrm{DM}$ ); dimensions are adjusted to common units. The current estimate of the intercept (equation [2]) seems to be statistically equal to the value reported by Weiss (2004). However, in contrast to Weiss (2004), true $\mathrm{Mg}$ absorption was used as an independent variable in the current study (equation [2]). Probably, estimated endogenous fecal $\mathrm{Mg}$ losses were too small compared with the total fecal $\mathrm{Mg}$ excretion to influence mean $\mathrm{Mg}$ absorption expressed as a percentage of intake.

With respect to the estimated coefficient of dietary $\mathrm{K}$ there seems to be a discrepancy between the value reported by Weiss (2004) and the value estimated in the current study (i.e., $0.75( \pm 0.35)$ and $-0.31( \pm 0.068)$, respectively). However, on the basis of $95 \%$ confidence intervals (Student's $t$ distribution, critical $t$-value $=2$ ), the values are not statistically different, primarily because of the large SE of the slope estimated by Weiss (2004). Indeed, in the present equation [2], both the intercept and the slope are accompanied by a relatively small standard error that is probably due to the much larger range in dietary $\mathrm{K}$ contents in the current data set (Table 1). Furthermore, it is difficult to see why a 
Table 2. General description of the rations and the status of the animals used to compose the current data set

Reference Description

Kemp et al. (1961)

Rogers and van't Klooster (1969)

Field and Suttle (1979)

Rahnema et al. (1994)

Schonewille et al. $(1994 a)^{1}$

Schonewille et al. (1994b)

Schonewille et al. (1994c)

Schonewille et al. (1997)

Schonewille et al. (1999)

Schonewille et al. (2000)

Schonewille and Beynen (2002)

Schonewille et al. (2002)

Jittakhot et al. (2004a)

Jittakhot et al. (2004b)

Jittakhot et al. (2004c)
Rations: fresh grass, no supplemental $\mathrm{K}$ or $\mathrm{Mg}$. Variation in the $\mathrm{K}$ and $\mathrm{Mg}$ contents of grass were due to different fertilization regimens.

Cows: midlactation, mean milk hield of about $15 \mathrm{~kg} / \mathrm{d}$ (range: 8 to $20 \mathrm{~kg} / \mathrm{d}$ ).

Rations: 4 hay-based rations supplemented with various amounts of by-product based concentrates and 1 ration with grass as the sole source of nutrition. One hay-based ration was supplemented with $100 \mathrm{~g}$ of $\mathrm{K} / \mathrm{cow}$ per $\mathrm{d}$ (mixture containing $85 \% \mathrm{KCl}$ and $15 \% \mathrm{~K}_{2} \mathrm{CO}_{3}$ ).

Cows: lactating, mean milk yield of about $11 \mathrm{~kg} / \mathrm{d}$ (range: 9 to $13 \mathrm{~kg} / \mathrm{d}$ ).

Rations: $1 \mathrm{~kg}$ of oat straw and about $4.5 \mathrm{~kg}$ of semipurified pellets with appropriate amount of calcinated magnesite (solubility not given) and $\mathrm{KCl}$.

Cows: monozygotic twins, nonlactating.

Rations: TMR containing chopped alfalfa hay, alfalfa haylage, corn silage and concentrate at 1:1:1:2 (DM). Rations were supplemented (maximum 5\% of total DM) with either Ca-salts of fatty acids or a mixture of animal-vegetable fat.

Cows: midlactation, milk yield was $20 \pm 0.9 \mathrm{~kg} / \mathrm{d}$.

Rations: corn silage $75 \%$ of total DMI. About $85 \%$ of $\mathrm{Mg}$ intake was derived from supplemental $\mathrm{MgO}{ }^{1}$ Rations were not supplemented $\mathrm{K}$.

Heifers: 4.5 to $7 \mathrm{mo}$ in gestation.

Rations: grass silage, corn silage and by-product based concentrate at 5.6:1.4:1 (DM). Treatments: Low and high $\mathrm{Ca}$. About $75 \%$ of total $\mathrm{Mg}$ intake was derived from a mixture of $\mathrm{MgO}^{1}$ and hydrated Mg-chloride at 1.5:1 (g). Rations were not supplemented with $\mathrm{K}$.

Cows: nonpregnant, dry.

Rations: grass silage $(63 \%, \mathrm{DM})$, corn silage $(24 \%, \mathrm{DM})$ and by-product based concentrate (13\%, DM). Treatments: DCAD +276 or $-170 \mathrm{mEq} / \mathrm{kg}$ hydrated Mg-sulfate at 1:5.7:1.5 (anion-rich). Rations were not supplemented with $\mathrm{K}$.

Cows: nonpregnant, dry.

Rations: grass silages of various origin and $0.5 \mathrm{~kg}$ of a beet pulp-based concentrate containing supplemental $\mathrm{MgO}^{1}$ which accounted for about $65 \%$ of total $\mathrm{Mg}$ intake.

Cows: nonpregnant, dry.

Rations: artificially dried grass and about $1 \mathrm{~kg}$ of a beet pulp-based concentrate. Treatments: Low intrinsic $\mathrm{K}(\mathrm{LK})$, high intrinsic $\mathrm{K}(\mathrm{HK})$ and $\mathrm{LK}+\mathrm{KHCO}_{3}$ (supplemental $\mathrm{K}$ is about $38 \%$ of total $\mathrm{K}$ intake). Rations did not contain supplemental $\mathrm{Mg}$.

Cows: nonpregnant, dry.

Rations: artificially dried grass and $2 \mathrm{~kg}$ of experimental concentrate containing either a mix of cellulose and corn gluten feed or native or popped cornmeal each at 2 levels equivalent to 11 or $20 \%$ starch (DM). Almost all $\mathrm{Mg}$ was intrinsically present in the feedstuffs, $\mathrm{K}$ was not supplemented.

Cows: nonpregnant, dry.

Rations: artificially dried grass and by-product based concentrate fed at either a 4:1 or a 1.5:1 ratio (energy basis). Rations were supplemented with $\mathrm{MgO} .{ }^{1}$ Supplemental $\mathrm{Mg}$ was either 46 (40\% concentrate) or $23 \%$ ( $20 \%$ concentrate) of total Mg intake. Rations did not contain supplemental K.

Cows: midlactation, initial milk yield was $12 \mathrm{~kg} / \mathrm{d}$, but dropped to $4 \mathrm{~kg} / \mathrm{d}$ in the course of the experiment.

Rations: artificially dried grass and by-product based concentrate fed at the following roughage/concentrate ratios 100:0, 80:20, 60:40 and 40:60 (energy basis). All rations were supplemented with a small amount of a $\mathrm{MgO}^{1}$ rich concentrate (maximum amount; $120 \mathrm{~g} / \mathrm{d}$ ). Supplemental $\mathrm{Mg}$ intake ranged from 22 (60\% concentrate) or $63 \%$ (no concentrate) of total $\mathrm{Mg}$ intake. Rations did not contain supplemental $\mathrm{K}$.

Cows: nonpregnant, dry.

Rations: artificially dried grass $(39 \%, \mathrm{DM})$, hay $(4 \%, \mathrm{DM})$ and by-product based concentrate $(57 \%, \mathrm{DM})$. Supplemental $\mathrm{Mg}$ (from $\mathrm{MgO}^{1}$ ) was either 32 (low $\mathrm{Mg}$ ) or $63 \%$ (high $\mathrm{Mg}$ ) of total $\mathrm{Mg}$ intake. Supplemental $\mathrm{K}\left(\mathrm{KHCO}_{3}\right)$ was about $30 \%$ of total $\mathrm{K}$ intake.

Cows: midlactation, milk yield $22 \mathrm{~kg} / \mathrm{d}$.

Rations: ingredient composition was exactly the same as used by Jittakhot et al. (2004a).

Supplemental $\mathrm{Mg}$ (from $\mathrm{MgO}^{1}$ ) ranged from 31 (lowest $\mathrm{Mg}$ intake) to 86\% (highest $\mathrm{Mg}$ intake) of total $\mathrm{Mg}$ intake. Supplemental $\mathrm{K}\left(\mathrm{KHCO}_{3}\right)$ is about $30 \%$ of total $\mathrm{K}$ intake.

Cows: nonpregnant, dry.

Rations: artificially dried grass $(40 \%, \mathrm{DM})$, hay $(4 \%, \mathrm{DM})$ and by-product based concentrate (56\%, DM). Supplemental $\mathrm{Mg}$ (from $\mathrm{MgO}^{1}$ ) ranged from 68 (low $\mathrm{Mg}$ intake) to $83 \%$ (high $\mathrm{Mg}$ intake) of total $\mathrm{Mg}$ intake. Supplemental $\mathrm{K}\left(\mathrm{KHCO}_{3}\right)$ ranged from 0 to $76 \%$ of total $\mathrm{K}$ intake.

Cows: nonpregnant, dry.

\footnotetext{
${ }^{1} \mathrm{Mg}$ was supplemented in the form of powdered $\mathrm{MgO}$ with an in vitro solubility of $95 \%$ (Schonewille et al., 1992).
} 
Table 3. Descriptive statistics for the data set $(n=68$ treatment means from 15 studies) used to generate the equations ${ }^{1}$

\begin{tabular}{lcccc}
\hline Item & Mean & SD & Minimum & Maximum \\
\hline BW, kg & 624 & 275.9 & 350 & 790 \\
DMI, kg/d & 8.8 & 8.39 & 4.4 & 18.6 \\
Mg content, g/kg of DM & 4.48 & 7.450 & 0.45 & 17.3 \\
K content, g/kg of DM & 30.3 & 29.19 & 6.9 & 75.6 \\
Mg intake, g/d & 37.7 & 59.59 & 2.3 & 124.3 \\
K intake, g/d & 258 & 288.6 & 55 & 607 \\
Apparent Mg absorption ${ }^{2}$ & & & & \\
g/d & 6.1 & 12.11 & 0.3 & 22.0 \\
\% of intake & 14.7 & 14.73 & 1.9 & 30.0 \\
True Mg absorption & & & & \\
g/d & 8.6 & 12.40 & 1.7 & 24.8 \\
\% of intake & 26.2 & 21.83 & 9.9 & 73.7 \\
\hline
\end{tabular}

${ }^{1}$ Means and standard deviations (SD) are corrected for the number of animals per treatment.

${ }^{2}$ Data not shown in Table 1.

smaller range in dietary $\mathrm{K}$ concentrations should result in a higher estimate of the coefficient associated with $\mathrm{K}$. It could be speculated that the somewhat greater mean K intake (g/d) in the data set used by Weiss (2004) is responsible for the numerical difference in calculated $\mathrm{K}$ associated coefficients. However, as far as we know, there are no studies reporting a depressant effect of $\mathrm{K}$ intake $(\mathrm{g} / \mathrm{d})$ on $\mathrm{Mg}$ absorption independent of the dietary $\mathrm{K}$ concentration ( $\mathrm{g} / \mathrm{kg}$ of $\mathrm{DM})$. This issue remains a matter of dispute.

The current estimate (equation [2]) of the inhibitory effect of dietary $\mathrm{K}$ on $\mathrm{Mg}$ absorption is derived from a data set in which grass feeds were the main source of roughage, whereas in the data set used by Weiss (2004), corn silage was the predominant form of roughage. Thus, it can be suggested that next to the dietary $\mathrm{K}$ content, the type of roughage is also relevant in relation to $\mathrm{Mg}$ absorption. However, as far as we know, there are no controlled studies reporting a $\mathrm{K} \times$ type of roughage interaction on $\mathrm{Mg}$ absorption.
It has been shown that the intake of extra $\mathrm{Mg}$ can counteract the inhibitory effect of dietary $\mathrm{K}$ on $\mathrm{Mg}$ absorption (Ram et al., 1998; Jittakhot et al., 2004c). However, when either Mg intake (g/d) or DMI and dietary $\mathrm{Mg}$ content ( $\mathrm{g} / \mathrm{kg}$ of $\mathrm{DM}$ ) were introduced as extra independent variables into equation [2], the residual standard error of the regression model was increased (Table 4). Apparently, Mg absorption expressed as a percentage of intake cannot be accurately predicted on the basis of the current data set. To account for the negative effect of dietary $\mathrm{K}$ on $\mathrm{Mg}$ absorption, the dietary $\mathrm{K}$ concentration $(\mathrm{g} / \mathrm{kg}$ of $\mathrm{DM})$ was added as an independent variable into equation [1], which resulted in the following equation (adjusted for trial effects):

$$
\begin{gathered}
\mathrm{Mg} \text { absorption }(\mathrm{g} / \mathrm{d})=3.6( \pm 0.67)+0.20( \pm 0.01) \\
\times \mathrm{Mg} \text { intake }(\mathrm{g} / \mathrm{d})-0.08( \pm 0.014) \\
\quad \times \text { dietary } \mathrm{K}(\mathrm{g} / \mathrm{kg} \text { of } \mathrm{DM}) .
\end{gathered}
$$

The $\mathrm{SE}_{\mathrm{TRIAL}}$ and $\mathrm{SE}_{\mathrm{RES}}$ were found to be 0.96 and 0.26 , respectively. The intercept and both the positive coefficient for $\mathrm{Mg}$ intake and the negative coefficient for dietary $\mathrm{K}$ are significantly different from zero $(P<$ 0.001 ). In the light of the low residual standard error, equation [3] seems to be suitable to predict absolute $\mathrm{Mg}$ absorption.

A similar equation was reported by Weiss (2004): $\mathrm{Mg}$ absorption $=4.5( \pm 4.0)+0.24( \pm 0.07) \times \mathrm{Mg}$ intake -0.44 $( \pm 0.22) \times$ dietary $\mathrm{K}$ (dimension of $\mathrm{K}$ is adjusted to $\mathrm{g} / \mathrm{kg}$ of DM). The current estimates of both the intercept and the coefficients (equation [3]) seem to be statistically equal to the values reported by Weiss (2004). The issue of numerical difference between the coefficients associated with dietary K reported by Weiss (2004) and the current study is already discussed in relation to equation [2].

Table 4. Outcome of 4 different regression models (PROC MIXED) to predict true Mg absorption expressed as a percentage of intake ${ }^{1}$

\begin{tabular}{llccccr}
\hline $\begin{array}{l}\text { Predictor } \\
\text { set }\end{array}$ & \multicolumn{1}{c}{ Predictor variables } & $S E_{\text {TRIAL }}$ & $S E_{R E S}$ & Coefficients & SE & $P$ \\
\hline 1 & 17.8 & 5.99 & 34.9 & 2.62 & $<0.001$ \\
& Intercept & & & -0.31 & 0.068 & $<0.001$ \\
2 & Dietary K (g/kg of DM) & 17.1 & 6.10 & 39.0 & 4.47 & $<0.001$ \\
& Intercept & & & -0.46 & 0.406 & 0.276 \\
& DMI (kg/d) & & & -0.30 & 0.068 & $<0.001$ \\
3 & Dietary K (g/kg of DM) & \multirow{2}{*}{13.0} & \multirow{2}{*}{6.46} & 43.8 & 4.27 & $<0.001$ \\
& Intercept & & & -0.58 & 0.345 & 0.115 \\
& DMI (kg/d) & & & -0.81 & 0.349 & 0.025 \\
& Dietary Mg (g/kg of DM) & & & -0.31 & 0.067 & $<0.001$ \\
4 & Dietary K (g/kg of DM) & \multirow{2}{*}{12.8} & 6.37 & 39.0 & 2.81 & $<0.001$ \\
& Intercept (g/d) & & & -0.11 & 0.042 & 0.015 \\
& Mg intake (g/d) & & & -0.31 & 0.067 & $<0.001$ \\
\hline
\end{tabular}

${ }^{1}$ Trial was included as a random class variable (St-Pierre, 2001). 
In Europe, grass feeds instead of corn silage are more commonly used as a main source of roughage. Therefore, grass feeds were the main source of roughage in the rations used to compile the current data set (Table 2 ). Thus, the current equation [3] is probably more suitable in grass-based rations. Indeed, when the equation reported by Weiss (2004) is applied to the current data set (mean $\mathrm{Mg}$ intake and dietary $\mathrm{K}$ are $37.7 \mathrm{~g} / \mathrm{d}$ and $30.3 \mathrm{~g} / \mathrm{kg}$ of DM respectively, Table 3), an amount of $0.2 \mathrm{~g} / \mathrm{d}$ apparent $\mathrm{Mg}$ absorption is predicted, whereas a mean of $6.1 \mathrm{~g} / \mathrm{d}$ was observed (Table 3 ). Thus, it seems that the coefficient associated with dietary $\mathrm{K}$ as reported by Weiss (2004) overestimates the inhibitory effect of $\mathrm{K}$ on $\mathrm{Mg}$ absorption, at least when grass-based rations are fed. On the basis of equation [3], it can be calculated that an increase in the dietary $\mathrm{K}$ content of $10 \mathrm{~g} / \mathrm{kg}$ of DM can be counteracted by an additional intake of $4 \mathrm{~g}$ of $\mathrm{Mg} / \mathrm{d}$ (coefficient of dietary $\mathrm{K} /$ coefficient of $\mathrm{Mg}$ intake multiplied by 10 ).

\section{CONCLUSIONS}

For predominantly grass-based rations associated with wide ranges in dietary $\mathrm{Mg}$ and $\mathrm{K}$ concentrations, a mean true $\mathrm{Mg}$ absorption of around $20 \%$ of intake was found. The inhibitory effect of dietary $\mathrm{K}$ on $\mathrm{Mg}$ absorption was accurately estimated, probably due to a wide range in dietary $K$ concentrations, and was found to be 0.31 percentage units/g of $\mathrm{K}$ in the DM. To maintain the amount of absorbed $\mathrm{Mg}$ when the dietary $\mathrm{K}$ content increases by $10 \mathrm{~g} / \mathrm{kg}$ of DM, Mg intake must be increased by $4 \mathrm{~g} / \mathrm{d}$.

\section{ACKNOWLEDGMENT}

The Product Board Animal Feed (Produktschap Diervoeder), The Hague, the Netherlands, is acknowledged for financial support.

\section{REFERENCES}

Adediji, O., and N. F. Suttle. 1999. Influence of diet type, potassium and animal species on the absorption of magnesium by ruminants. Proc. Nutr. Soc. 58:31A.

Aikawa, J. K. 1981. Magnesium. Its biological significance. CRC Press, Boca Raton, FL.

Barber, P. A. M., C. L. Wright, and W. MacLennan. 1983. Hypomagnesaemia in periparturient dairy cows. Vet. Rec. 112:35-36.

Brown, R. C., A. D. Care, and D. W. Pickard. 1978. Magnesium absorption from the rumen of sheep. J. Physiol. 276:62P-63P.

Care, A. D., R. C. Brown, A. R. Farrar, and D. W. Pickard. 1984. Magnesium absorption from the digestive tract of sheep. Q. J. Exp. Physiol. 69:577-587.

CVB (Centraal Veevoederbureau). 1996. Handleiding mineralenvoorziening rundvee in de praktijk. 5e druk. CVB, Lelystad, the Netherlands.

CVB (Centraal Veevoederbureau). 2005a. Tabellenboek Veevoeding 2005. Voedernormen landbouwhuisdieren en voederwaarde veevoeders. CVB, Lelystad, the Netherlands.
CVB (Centraal Veevoederbureau). 2005b. Handleiding mineralenvoorziening rundvee, schapen en geiten. 6e druk. CVB, Lelystad, the Netherlands.

Field, A. C., and N. K. Suttle. 1979. Effect of high potassium and low magnesium intakes on metabolism of monozygotic twin cows. J. Comp. Pathol. 89:431-439.

Fontenot, J. P., M. B. Wise, and K. E. Webb, Jr. 1973. Interrelationships of potassium, nitrogen, and magnesium in ruminants. Fed. Proc. 32:1925-1928.

Gäbel, G., and H. Martens. 1986. The effect of ammonia on magnesium metabolism in sheep. J. Anim. Physiol. Anim. Nutr. (Berl.) 55:278-287.

Grace, N. D., and J. C. MacRae. 1972. Influence of feeding regimen and protein supplementation on the sites of net absorption of magnesium in sheep. Br. J. Nutr. 27:51-55.

Jittakhot, S., J. T. Schonewille, H. Wouterse, E. J. Focker, C. Yuangklang, and A. C. Beynen. 2004a. Effect of high magnesium intake on apparent magnesium absorption in lactating cows. Anim. Feed Sci. Technol. 113:53-60.

Jittakhot, S., J. T. Schonewille, H. Wouterse, A. W. J. Uijttewaal, C. Yuangklang, and A. C. Beynen. 2004b. Increasing magnesium intakes in relation to magnesium absorption in dry cows. J. Dairy Res. 71:297-303.

Jittakhot, S., J. T. Schonewille, H. Wouterse, C. Yuangklang, and A. C. Beynen. 2004c. Apparent magnesium absorption in dry cows fed at 3 levels of potassium and 2 levels of magnesium intake. J. Dairy Sci. 87:379-385.

Kemp, A. 1960. Hypomagnesaemia in milking cows: The response of serum magnesium to alterations in herbage composition resulting from potash and nitrogen dressings on pasture. Neth. J. Agric. Sci. 8:281-303.

Kemp, A., W. B. Deijs, O. J. Hemkes, and A. J. H. Van Es. 1961. Hypomagnesaemia in milking cows: Intake and utilization of magnesium from herbage by lactating cows. Neth. J. Agric. Sci. 9:134-149.

Leonhard, S., H. Martens, and G. Gäbel. 1989. New aspects of magnesium transport in ruminants. Acta Vet. Scand. 86(Suppl.):146151.

Leonhard-Marek, S., and H. Martens. 1996. Effects of potassium on magnesium transport across rumen epithelium. Am. J. Physiol. 271:G1034-G1038.

Martens, H. 1979. In vivo Untersuchungen ber die Absorption von Magnesium aus dem Pansen von Schafen. Eine Abschätzung der maximalen Absorptionskapazität des Pansens. Berl. Münch. Tierärtzl. Wochenschr. 92:152-155.

Martens, H., G. Gäbel, and H. Strozyk. 1987. The effect of potassium and the transmural potential difference on magnesium transport across an isolated preparation of sheep rumen epithelium. Q. J. Exp. Physiol. 72:181-188.

Moore, W. F., J. P. Fontenot, and K. E. Webb, Jr. 1972. Effect of form and level of nitrogen on magnesium utilization. J. Anim. Sci. 35:1046-1053.

Rahnema, S., Z. Wu, O. A. Ohajuruka, W. P. Weiss, and D. L. Palmquist. 1994. Site of mineral absorption in lactating cows fed highfat diets. J. Anim. Sci. 72:229-235.

Ram, L., J. T. Schonewille, A. T. van't Klooster, H. Wouterse, and A. C. Beynen. 1998. Magnesium absorption by wethers fed potassium bicarbonate in combination with different dietary magnesium concentrations. J. Dairy Sci. 81:2485-2492.

Rogers, P. A. M., and A. T. van't Klooster. 1969. The fate of Na, K, $\mathrm{Ca}, \mathrm{Mg}$ and $\mathrm{P}$ in the digesta. Mededelingen Landbouwhogeschool Wageningen 69:26-39.

Rook, J. A. F., R. C. Campling, and V. W. Johnson. 1964. Magnesium in the dairy cow VI. Metabolism on artificial diets low in magnesium. J. Agric. Sci. (Camb.) 62:273-279.

Ryan, M. F. 1991. The role of magnesium in clinical biochemistry: An overview. Ann. Clin. Biochem. 28:19-26.

SAS Institute. 2003. SAS/STAT User's guide, Version 9.1.3. SAS Institute, Inc., Cary, NC.

Schonewille, J. T. 1999. Magnesium absorption in ruminants. PhD thesis. Utrecht University, Utrecht, the Netherlands. 
Schonewille, J. T., and A. C. Beynen. 2002. Iso-energetic replacement of artificially dried grass by concentrate increases magnesium absorption in cows (a short communication). Folia Vet. 46:72-74.

Schonewille J. T., and A. C. Beynen. 2005. Reviews on the mineral provision in ruminants (III): Magnesium metabolism and requirements in ruminants. CVB Dokumentatierapport nr. 35. Centraal Veevoederbureau (CVB), Lelystad, the Netherlands.

Schonewille, J. T., L. Ram, A. T. van't Klooster, H. Wouterse, and A. C. Beynen. 1997. Intrinsic potassium in grass silage and magnesium absorption in dry cows. Livest. Prod. Sci. 48:99-110.

Schonewille, J. T., A. T. van't Klooster, and A. C. Beynen. 1994a. High phosphorus intake depresses apparent magnesium absorption in pregnant heifers. J. Anim. Physiol. Anim. Nutr. (Berl.) 71:15-21.

Schonewille, J. T., A. T. van't Klooster, and A. C. Beynen. 1994b. The addition of extra calcium to a chloride-rich ration does not affect the absolute amount of calcium absorbed by non-pregnant, dry cows. J. Anim. Physiol. Anim. Nutr. (Berl.) 72:272-280.

Schonewille, J. T., A. T. van't Klooster, J. W. Cone, H. J. KalsbeekVan der Valk, H. Wouterse, and A. C. Beynen. 2000. Neither native nor popped cornmeal in the ration of dry cows affects magnesium absorption. Livest. Prod. Sci. 63:17-26.

Schonewille, J. T., A. T. van't Klooster, A. Dirkzwager, and A. C. Beynen. 1994c. Stimulatory effect of an anion(chloride)-rich ration on apparent calcium absorption in dairy cows. Livest. Prod. Sci. 40:233-240.
Schonewille, J. T., A. T. van't Klooster, and M. van Mosel. 1992. A comparative study of the in vitro solubility and availability of magnesium from various sources for cattle. Tijdschr. Diergeneeskd. 117:105-108.

Schonewille, J. T., A. T. van't Klooster, H. Wouterse, and A. C. Beynen. 1999. Effects of intrinsic potassium in artificially dried grass and supplemental potassium bicarbonate on apparent magnesium absorption in dry cows. J. Dairy Sci. 82:1824-1830.

Schonewille, J. T., H. Wouterse, and A. C. Beynen. 2002. Iso-energetic replacement of artificially dried grass by pelleted concentrate on apparent magnesium absorption in dry cows. Livest. Prod. Sci. 76:59-69.

Simesen, M. G., T. Lunaas, T. A. Rogers, and J. R. Luick. 1962. The endogenous excretion of magnesium in cattle. Acta Vet. Scand. 3:175-184.

Sjollema, B. 1930. On the nature of grass staggers. Vet. Rec. $10: 425-430$

St-Pierre, N. R. 2001. Invited review: Integrating quantitative findings from multiple studies using mixed model methodology. J. Dairy Sci. 84:741-755.

Van Leengoed, L. A. M. G. 1979. Het voorkomen van hypomagnesemie bij droogstaande koeien. Tijdschr. Diergeneeskd. 104:431-433.

Weiss, W. P. 2004. Macromineral digestion by lactating cows: Factors affecting digestibility of magnesium. J. Dairy Sci. 87:2167-2171. 